\title{
Analysis of Informal Microfinance Institutions Structures in Relation to Performance in Tharaka South Subcounty, Kenya
}

\author{
By Caxton Gitonga Kaua ${ }^{1 *}$, Thuita Thenya ${ }^{2}$, Jane Mutheu Mutune ${ }^{3}$
}

\begin{abstract}
Informal microfinance is the delivery of financial services mainly to low income people outside the regulation of the monetary authority. Despite their importance in development, no studies have undertaken a detailed analysis of structures and performance in informal microfinance institutions. This study aims to analyze structures and performance in informal microfinance institutions in Tharaka South Sub County. It uses descriptive study design and multi stage sampling design. Data analysis was done using thematic, descriptive and Kendall's tau-b correlation analysis. An informal microfinance performance index was developed using inductive and hierarchical approaches. The study found the informal microfinance institutions are marked by high performance which is determined by their structures. Moreover, the study deduced that informal microfinance is a key policy strategy for poverty alleviation, financial inclusion, gender equity and resilience building since participants mainly include women and other vulnerable groups.
\end{abstract}

Keywords: Capital, Livelihoods, Informal, Microfinance, Performance, social

\section{Introduction}

Informal microfinance involves delivery of small loans and savings mainly to poor and low income people who have little or no access to formal financial services (Hammil et al. 2008; Thrikawala et al. 2013) outside the regulation of the monetary authority (Owusu et al. 2013). They are a strategy by low income people to address their financial marginalization from formal financial services (Hammil et al. 2008; Tilakaratna 1996). Informal microfinance institutions include rotational saving and credit associations and accumulated savings and credit associations (Kaburi et al. 2013).

Informal microfinance institutions enable members to mobilize savings and access credit and are mainly marked by low default rates (Osei-Assibey 2011; Gugerty 2007; Swain and Flero 2007). Besides, they enable members to accumulate capital assets, access essential services and undertake livelihood activities including production and entrepreneurialship activities (Oppiah et al. 2016; Mushuku and Mayisha 2014; Moser and Farias 2014).

Despite the vital role of informal microfinance institutions in development, the informal finance sector in Africa has not been clearly defined of which undermines its development (Njeri et al. 2013). Studies analyzing structures of informal microfinance institutions are scanty. Furthermore, no past studies have analyzed performance in

${ }^{1} \mathrm{PhD}$ Student at Wangari Maathai Institute of Peace and Environmental Studies, University of Nairobi,

${ }^{2}$ Senior Lecturer at Wangari Maathai Institute of Peace and Environmental Studies, University of Nairobi,

${ }^{3}$ Lecturer at Wangari Maathai Institute of Peace and Environmental Studies, University of Nairobi, Kenya 
informal microfinance institutions. Past studies on microfinance in Tharaka South Subcounty including (Kiplimo et al. 2015; Machira et al. 2014) only focused on the formal microfinance sector. A detailed context specific analysis of informal microfinance institutions is thus imperative to inform efforts aimed at improving their structures and enhancing their performance.

Informal microfinance institutions are founded on social capital which facilitates individuals to cooperate and coordinate their activities in pursuit of shared objectives for mutual benefit through collective action (Putnam 1995; Coleman 1988; Ostrom and Ahn 2009; Bourdieu 1989). Social capital in informal microfinance institutions helps to assess individual's financial risk and viability (Mushuku and Mayisha, 2014) and thus provides social collateral (Chiteji 2002). Mwangi and Ouma (2012) notes that enforcement of contracts in informal microfinance institutions is not based on legal systems but is embedded on social capital. Social capital enables access to private information thus reducing transaction, monitoring and enforcement costs (Mwangi and Ouma 2012) and helping overcome problems associated with asymmetric information, adverse selection and moral hazard (Gomez and Santor 2001). Besides, Gugerty (2007) observes that informal microfinance institutions enable saving by providing a collective mechanism for individual self-control in the presence of time inconsistent preferences.

\section{Study Area}

Tharaka South Sub County is part of Tharaka Nithi County and lies to the East of Mount Kenya.

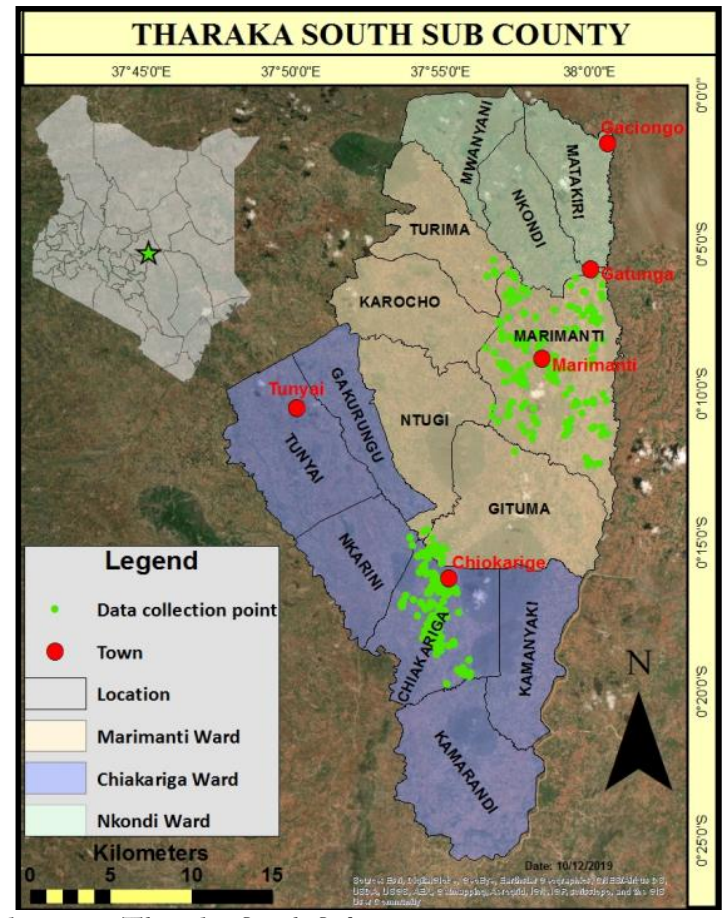

Figure 1: Location of study area in Tharaka South Subcounty 
It covers a surface area of $637 \mathrm{KM}^{2}$ (Government of Kenya 2019). Tharaka South Sub County has a total population of 75,250 people and a population density of 118 people per $\mathrm{KM}^{2}$ (Government of Kenya 2019). The sub county has 18,466 households with the average household size therefore being 4 people per household. The subcounty has three main livelihood zones namely the mixed farming zone, marginal mixed farming zone and the rain fed farming zone (Government of Kenya 2008). People in Tharaka South Subcounty are therefore largely agropastoralists with farming and animal husbandry accounting for over 70\% of their income (Kirraine et al. 2012). Informal microfinance institutions are the main source of financial services in the subcounty. These informal microfinance institutions are accumulated savings and credit associations which are member based associations in which members engage in savings and lending activities. There are approximately 400 informal microfinance institutions engaged in savings and lending activities in Tharaka South Subcounty.

\section{Materials and Methods}

The study used a descriptive study design. It employed multi stage sampling design. Two Locations i.e. Marimanti and Chiakariga were first selected randomly. An inventory of informal microfinance groups was then created based on data sourced from the department of social development. 36 study groups, 18 from each location, were then selected systematically selected from each of the study locations picking every $5^{\text {th }}$ group from the inventory lists. 11 respondents were then chosen systematically from each group leading to selection of 385 respondents. The studys' sample size was determined using Cochrans' (1963) Equation 1.

Data collection was done using focused group discussions, key informant interviews, observation and questionnaire surveys. This was done with the assistance of a mobile based georeferenced data management system called kMACHO. Methodological triangulation was used to cross verify, validate and harmonize data from different data collection methods. Pilot testing of the data collection instruments was done to check for weaknesses in design and instrumentation. The data collection instruments were evaluated for validity through expert consultation. The instruments were tested for reliability using the Cronbach Alpha method which tests the degree of internal consistency between items. A Cronbach alpha of 0.774 was arrived at indicating good reliability.

Data analysis was done using thematic analysis, descriptive analysis, and Kendall's tau-b correlation analysis. An informal microfinance performance index was developed using inductive and hierarchical approaches. This used three variables including savings (members contribution per month), loan access (total amount of loan borrowed by members) and loan repayment performance (Number delayments in loan repayment).

In developing the index, the negative oriented values were first adjusted for directionality using multiplicative inverse adjustment to ensure higher values always indicate higher loan repayment performance i.e.

$x_{i}=1 / x_{u}$

Where:

$x_{i}=$ Adjusted value of $\mathrm{x}$ 
$x_{u}=$ Unadjusted value of $\mathrm{x}$

The variables were then normalized to ensure comparability of indicators bearing different measurement units and scales. This was done using the Min-Max normalization to yield a standard index value with relative positions in the range of zero to one for each indicator i.e.

$z_{i}=x_{i}-\min (x) / \max (x)-\min (x)$

Where:

$Z_{i}=$ Normalized value of $\mathrm{x}_{\mathrm{i}}$

$\min (x)=$ Minimum value of $\mathrm{x}$

$\max (x)=$ Maximum value of $\mathrm{x}$

These indicators were then weighted to avoid uncertainty of equal weights given their diversity. This entailed weighting the variables using the pairwise ranking matrix. This allocated weights according to the number of times a variable was chosen as being more important than the other variables.

The member's informal microfinance performance composite index was then calculated using the formula:

$C I=\sum\left(w_{i} z_{i}\right) / n$

Where:

$C I=$ Composite index

$w_{i}=$ Weight of variable

$z_{i}=$ Variable index value

$n=$ Number of variables

The member's informal microfinance performance composite index was tested for accuracy and robustness using uncertainty and sensitivity analysis. Uncertainty analysis was done using the propagation of standard errors approach i.e. based on uncertainties of index components. This involved adding their standard errors as a weighted sum in quadrature (squared, weighted, added and then square rooted) as in Kirchner (2001) i.e.

$U=\sqrt{ } \sum\left(w_{i} S_{i}\right)^{2}$

Where:

$U=$ Uncertainty

$w_{i}=$ Variable weight

$S_{i}=$ Standard error of variable index value

Sensitivity analysis was done using multiple regression analysis to determine how components constituting the composite index influence it as in Hamby (1995). In doing this the coefficient of determination $\left(\mathrm{R}^{2}\right)$ gave an indication of the amount of variation in the composite index which can be explained by the model's components.

\subsection{Coding of categorical variables}

The categorical variables in the study were coded as illustrated in Table 1.

Table 1: Coding of variables

\begin{tabular}{|l|l|l|}
\hline \multicolumn{2}{|l|}{ Coding of categorical variables } \\
\hline$\#$ & Variable & Coding \\
\hline 1 & Gender & $1=$ Male \\
\cline { 3 - 3 } & & $2=$ Female \\
\hline
\end{tabular}




\begin{tabular}{|c|c|c|}
\hline \multicolumn{3}{|c|}{ Coding of categorical variables } \\
\hline$\#$ & Variable & Coding \\
\hline \multirow[t]{3}{*}{2} & \multirow[t]{3}{*}{ Age } & $1=18-35$ \\
\hline & & $2=36-60$ \\
\hline & & $3=>60$ \\
\hline \multirow[t]{5}{*}{3} & \multirow[t]{5}{*}{ Marital status } & $1=$ Married \\
\hline & & $2=$ Separated \\
\hline & & $3=$ Single \\
\hline & & $4=$ Widowed \\
\hline & & $5=$ Divorced \\
\hline \multirow[t]{7}{*}{4} & \multirow[t]{7}{*}{ Level of education } & $1=$ None \\
\hline & & $2=$ Nursery \\
\hline & & $3=$ Primary uncompleted \\
\hline & & $4=$ Primary completed \\
\hline & & $5=$ Secondary uncompleted \\
\hline & & $6=$ Secondary completed \\
\hline & & $7=$ Tertiary \\
\hline \multirow[t]{2}{*}{5} & \multirow[t]{2}{*}{ If head of household } & $1=$ Yes \\
\hline & & $2=\mathrm{No}$ \\
\hline \multirow[t]{2}{*}{6} & \multirow[t]{2}{*}{ How household is headed } & $1=$ Male headed \\
\hline & & $2=$ Female headed \\
\hline \multirow[t]{2}{*}{7} & \multirow[t]{2}{*}{ Group composition by gender } & Female and male members \\
\hline & & Female members only \\
\hline \multirow[t]{2}{*}{8} & \multirow[t]{2}{*}{ If member holds leadership position } & $1=$ Yes \\
\hline & & $2=\mathrm{No}$ \\
\hline \multirow[t]{2}{*}{9} & \multirow[t]{2}{*}{ Gender of officials } & $1=$ Male \\
\hline & & $2=$ Female \\
\hline \multirow[t]{2}{*}{10} & \multirow[t]{2}{*}{ Gender of chairperson } & $1=$ Male \\
\hline & & $2=$ Female \\
\hline \multirow[t]{2}{*}{11} & \multirow[t]{2}{*}{ Chairperson leadership positions in other groups } & $1=$ Yes \\
\hline & & $2=\mathrm{No}$ \\
\hline \multirow[t]{2}{*}{12} & \multirow[t]{2}{*}{ Allowances to officials } & $1=$ Yes \\
\hline & & $2=\mathrm{No}$ \\
\hline \multirow[t]{2}{*}{13} & \multirow[t]{2}{*}{ Group access to external funding } & $1=$ Yes \\
\hline & & $2=\mathrm{No}$ \\
\hline \multirow[t]{2}{*}{14} & \multirow[t]{2}{*}{ Follow up of borrowers } & $1=$ Yes \\
\hline & & $2=\mathrm{No}$ \\
\hline
\end{tabular}

\section{Results}

\subsection{Membership characteristics}

In terms of gender composition, $21.3 \%$ of the members are male while $78.7 \%$ are female. Only $12.6 \%$ of the female members have received post primary school education compared to $15.9 \%$ of the male members. Moreover only $26.7 \%$ of the female members are household heads while $95.1 \%$ of male members are household heads. Female members belong to more groups than male members as confirmed by the Kendall's tau $\mathrm{b}$ correlation analysis i.e. $\left(\tau_{b}=0.161^{* *}, P<0.05\right)$. Besides, $58.7 \%$ of the 
female members belong to mixed membership groups and $41.3 \%$ belong to female member's only groups.

The members belong to different age categories with $28.1 \%$ aged between $18-35$ years, $59.1 \%$ aged between $36-60$ years and $12.5 \%$ being over 60 years old. Younger people are more educated since $35.4 \%$ of those aged over 60 year have not attained any formal education compared to only $1.9 \%$ for those aged $18-35$ years and $5.7 \%$ for those aged 36-60 years. Only 18.5\% of those aged 18-35 years head a household while $48.5 \%$ of those aged 36-60 years and 58.3\% of those aged over 60 years old are household heads. Older members have larger households as affirmed by Kendall's tau b correlation analysis i.e. $\left(\tau_{b}=0.150^{* *}, P<0.05\right)$. Younger members belong to more groups than older members i.e. $\left(\tau_{b}=-0.031, P>0.05\right)$. Older members have however belonged to informal microfinance institutions for a longer period i.e. $\left(\tau_{b}=0.201 * *, P<0.05\right)$.

The members have attained different levels of education with $8.3 \%$ having no formal education while $40.8 \%$ have attained nursery school level education. Moreover, 34.5\% have completed primary school, $3.1 \%$ attended primary school but didn't complete and $7.0 \%$ completed secondary school while 5.2\% attended secondary school but did not complete. $1.0 \%$ of the respondents have attained tertiary level education. Similarly, women in male headed households are more educated with $13.9 \%$ having attained post primary education as compared to $10.9 \%$ of those in female headed households. The level of education has a negative correlation with household size $\left(\tau_{b}=-0.093^{* *}, P<0.05\right)$. Moreover, the level of education has positive correlation with number of informal microfinance institutions belonged to $\left(\tau_{b}=0.133 * *, P<0.05\right)$.

Most of the members i.e. $80.5 \%$ are married. Moreover, $5.2 \%$ are separated, $7 \%$ are single, and $6.2 \%$ were windowed while $1 \%$ are divorced. The study observes that $68.7 \%$ of the married members are not household's heads with $95.5 \%$ of them belonging to male headed households. Married members have larger households as confirmed by Kendall's tau b correlation analysis i.e. $\left(\tau_{b}=-0.129 * *, P<0.05\right)$. Non-married members belong to more groups i.e. $\left(\tau_{b}=0.090, P>0.05\right)$. Besides, $64.5 \%$ of those who are married belong to mixed membership groups while $35.5 \%$ belong to female member's only groups.

The study observed that $41.3 \%$ of the members are household heads while $58.7 \%$ were not household heads. Those who are heads of households belong to more informal microfinance institutions $\left(\tau_{b}=0.057, P>0.05\right)$. Further, $80.8 \%$ of the members households are male headed while 19\% were female headed. Female headed households have less access to capital assets as measured based on the value of household's crop and livestock production $\left(\tau_{b}=-0.003, P>0.05\right)$. Members from female headed households belong to more informal microfinance institutions $\left(\tau_{b}=0.091, P>0.05\right)$. Members in male headed households have higher formal education with $13.9 \%$ having attained post primary education as compared to $10.9 \%$ of those in female headed households.

In terms of gender composition, $66.7 \%$ of the informal microfinance institutions constitute of mixed membership i.e. both male and female members while $33.3 \%$ constitute female members only. Female members only groups have more members $\left(\tau_{b}\right.$ $=0.062, P>0.05)$ and are older $\left(\tau_{b}=0.248^{* *}, P<0.05\right)$ than mixed membership groups.

The average member's household size is 6 members. Household has a positive correlation with access to capital assets as measured based on value of the households crop and livestock production $\left(\tau_{b}=0.038, P>0.05\right)$. The membership characteristics that 
define the structure of informal microfinance institutions are further illustrated in are further illustrated in Table 2.

Table 2: Membership characteristics

\begin{tabular}{|c|c|c|c|}
\hline \multicolumn{4}{|c|}{ Informal microfinance institutions membership characteristics } \\
\hline \# & Variable & Statistic & Value \\
\hline \multirow[t]{4}{*}{1} & \multirow{4}{*}{ Household size } & Average & 6 \\
\hline & & Minimum & 1 \\
\hline & & Maximum & 15 \\
\hline & & Standard deviation & 2.37 \\
\hline \multirow[t]{4}{*}{2} & \multirow[t]{4}{*}{ Member's number of groups } & Average & 2 \\
\hline & & Minimum & 1 \\
\hline & & Maximum & 6 \\
\hline & & Standard deviation & 1.027 \\
\hline \multirow[t]{4}{*}{3} & \multirow[t]{4}{*}{ Member's years of membership } & Average & 11 \\
\hline & & Minimum & 1 \\
\hline & & Maximum & 41 \\
\hline & & Standard deviation & 8.857 \\
\hline \multirow[t]{4}{*}{4} & \multirow[t]{4}{*}{ Age of group (years) } & Average & 12 \\
\hline & & Minimum & 1 \\
\hline & & Maximum & 37 \\
\hline & & Standard deviation & 10.25 \\
\hline \multirow[t]{4}{*}{5} & \multirow[t]{4}{*}{ Number of group members } & Average & 21 \\
\hline & & Minimum & 12 \\
\hline & & Maximum & 42 \\
\hline & & Standard deviation & 6.629 \\
\hline \multirow[t]{4}{*}{6} & \multirow[t]{4}{*}{ Number of female members } & Average & 17 \\
\hline & & Minimum & 5 \\
\hline & & Maximum & 34 \\
\hline & & Standard deviation & 7.595 \\
\hline \multirow[t]{4}{*}{7} & \multirow[t]{4}{*}{ Number of male members } & Average & 5 \\
\hline & & Minimum & 1 \\
\hline & & Maximum & 24 \\
\hline & & Standard deviation & 6.231 \\
\hline
\end{tabular}

\subsection{Leadership characteristics}

The informal microfinance institutions are formed and governed participatorily. This is mainly done through regular group meetings. All the informal microfinance institutions have a strategy which stipulates the group's objectives and the activities to be undertaken. All the informal microfinance institutions have bylaws which are developed by the members. Informal microfinance institutions are however supported by government and non-government organizations in their activities. The groups are overseen and registered by the department of social development.

The informal microfinance institutions are marked by various leadership characteristics that define their structure. The study found $44.7 \%$ of the members interviewed hold leadership positions with $23.8 \%$ of the leader's being male while $76.2 \%$ were female. The 
informal microfinance institutions have an average of 6 officials. The average number of female officials is 5 while the average number of male officials is 2 .

The chairperson in $30.6 \%$ of the informal microfinance institutions is male while $69.4 \%$ have female chairpersons. Informal microfinance institutions that are led by female chairpersons have shorter terms of office as confirmed by Kendall's tau b correlation analysis $\left(\tau_{b}=-0.160^{* *}, P<0.05\right)$. Female led informal microfinance institutions also have less number of officials than those that are led by a male chairperson $\left(\tau_{b}=-0.020\right.$, $P>0.05)$. Female led informal microfinance institutions have less male officials than those led by a male chairperson $\left(\tau_{b}=-0.650^{* *}, P<0.05\right)$. On the other hand, female led informal microfinance institutions have more female officials than those led by a male chairperson $\left(\tau_{b}=0.619 * *, P<0.05\right)$.

Only $21 \%$ of the groups that are led by female chairpersons give allowances to officials as compared to $44.9 \%$ of those led by a male chairperson. Female chairpersons have held leadership positions in informal microfinance institutions for a longer period than male chairpersons $\left(\tau_{b}=-0.020, P>0.05\right)$. Besides, female chairpersons have less education with $11.6 \%$ having no formal education and $23.2 \%$ having attended post primary education as compared to male chairpersons who all have attained some formal education and $27.1 \%$ have attained post primary education. As appertains to the number of leadership positions held in informal microfinance institutions, female chairpersons hold less leadership positions compared to male chairpersons $\left(\tau_{b}=-0.169 * *, P<0.05\right)$.

The average period the chairpersons have held leadership positions in informal microfinance institutions is 11 years. The period the chairperson has held leadership positions in informal microfinance institutions is positively related with the length of the group's term of office $\left(\tau_{b}=0.048, P>0.05\right)$. It is also positively related to the group's number of officials $\left(\tau_{b}=0.012, P>0.05\right)$. Moreover, the period the chairperson has held leadership positions is positively related with the number of leadership positions they hold in informal microfinance institutions $\left(\tau_{b}=0.163^{* *}, P<0.05\right)$.

Furthermore, $55.6 \%$ of the group chairpersons hold more leadership positions in other informal microfinance institutions. The number of leadership positions which the chairperson holds in informal microfinance institutions has a positive correlation with the term of office of officials $\left(\tau_{b}=0.068, P>0.05\right)$. It however has a negative relationship with the number of officials in the informal microfinance institution $\left(\tau_{b}=-0.100^{*}\right.$, $P<0.05)$. Besides the number of officials in an informal microfinance institutions is negatively related to the length of the term of office $\left(\tau_{b}=-0.001, P>0.05\right)$.

The chairpersons in $8.3 \%$ of the informal microfinance institutions have no formal education, $11.1 \%$ have attended primary school but not completed while $55.6 \%$ have attended primary school and completed. Chairpersons in $2.8 \%$ of the informal microfinance institutions have attended secondary school education and $13.9 \%$ have attended secondary school and completed. Chairpersons in $8.3 \%$ of the informal microfinance institutions have attended tertiary level of education. The level of education of the chairperson has a negative correlation with the number of group officials $\left(\tau_{b}=\right.$ $0.029, P>0.05)$. The level of education of the chairperson also has a negative correlation with the number female officials in a group $\left(\tau_{b}=-0.085, P>0.05\right)$. On the other hand the level of education of the chairperson also has a positive correlation with the number male officials in a group $\left(\tau_{b}=0.124, P>0.05\right)$. 
Moreover, the level of education of the chairperson has a positive correlation with the term of office for officials $\left(\tau_{b}=0.006, P>0.05\right)$. It has a negative correlation with the number of years the chairperson has held leadership positions in informal microfinance institutions $\left(\tau_{b}=\right.$ - $\left.0.363^{* *}, P<0.05\right)$. In addition, the chairperson's level of educated is negatively correlated to the number of leadership positions the chairperson holds in informal microfinance institutions $\left(\tau_{b}=-0.005, P>0.05\right)$. Chairpersons who are more educated mainly belong to groups that don't give allowances to officials. This is because only $11.9 \%$ of chairpersons who have attained post primary education belong to groups that give allowances compared to $32.8 \%$ of chairpersons who have not attained post primary education.

Officials in $27.8 \%$ of the informal microfinance institutions are paid allowances while $72.2 \%$ do not give allowances to their officials. Further, $20 \%$ of officials from informal microfinance institutions that give allowances observe the allowances given are adequate while $80 \%$ observe the allowances are not adequate. Chairpersons in groups that give allowances to officials have held leadership positions in informal microfinance institutions for a longer period as confirmed by Kendall's tau-b statistical test i.e. $\left(\tau_{b}=\right.$ $\left.0.283^{* *}, P<0.05\right)$. The chairpersons in groups that give allowances to officials also hold more leadership positions in informal microfinance institutions $\left(\tau_{b}=-0.274^{* *}, P<0.05\right)$. Furthermore, informal microfinance institutions that give allowances to officials have a higher number of group officials $\left(\tau_{b}=0.004, P>0.05\right)$ and longer terms of office for officials i.e. $\left(\tau_{b}=-0.321 * *, P<0.05\right)$.

The leadership characteristics that define the structure of informal microfinance institutions are further illustrated in Table 3.

Table 3: Leadership characteristics

\begin{tabular}{|c|c|c|c|}
\hline \multicolumn{4}{|c|}{ Leadership characteristics } \\
\hline$\#$ & Variable & Statistic & Value \\
\hline \multirow[t]{4}{*}{1} & \multirow[t]{4}{*}{ Number of officials } & Average & 6 \\
\hline & & Minimum & 3 \\
\hline & & Maximum & 9 \\
\hline & & Standard deviation & 1.713 \\
\hline \multirow[t]{4}{*}{2} & \multirow[t]{4}{*}{ Number of male officials } & Average & 2 \\
\hline & & Minimum & 1 \\
\hline & & Maximum & 7 \\
\hline & & Standard deviation & 2.106 \\
\hline \multirow[t]{4}{*}{3} & \multirow[t]{4}{*}{ Number of female officials } & Average & 5 \\
\hline & & Minimum & 2 \\
\hline & & Maximum & 9 \\
\hline & & Standard deviation & 1.957 \\
\hline \multirow[t]{4}{*}{4} & \multirow[t]{4}{*}{ Term of office (years) } & Average & 1.7 \\
\hline & & Minimum & 0.5 \\
\hline & & Maximum & 6 \\
\hline & & Standard deviation & 1.094 \\
\hline \multirow[t]{4}{*}{5} & \multirow[t]{4}{*}{ Number of years chairperson has held groups leadership } & Average & 11 \\
\hline & & Minimum & 0.5 \\
\hline & & Maximum & 39 \\
\hline & & Standard deviation & 11.194 \\
\hline
\end{tabular}




\begin{tabular}{|c|l|l|c|}
\hline \multicolumn{2}{|l|}{ Leadership characteristics } \\
\hline$\#$ & Variable & Statistic & Value \\
\hline 6 & Number of leadership positions held by chairperson & Average & 1 \\
\cline { 3 - 4 } & & Minimum & 1 \\
\cline { 3 - 4 } & Maximum & 4 \\
\cline { 3 - 4 } & Standard deviation & 1.12 \\
\hline
\end{tabular}

\subsection{Performance in informal microfinance institutions}

\subsubsection{Savings contribution}

The average length of the full cycle in the informal microfinance institutions i.e. the period between the beginning of the savings and lending cycle and the auction audit date is 14.3 months. The length of the full cycle has a positive correlation with length of the contribution cycle as confirmed by Kendall's tau-b statistical test i.e. $\left(\tau_{b}=0.162^{* *}\right.$, $P<0.05)$. It has a negative correlation with the minimum contribution per cycle $\left(\tau_{b}=-\right.$ $\left.0.122^{* *}, P<0.05\right)$. The full cycle also has a negative correlation with the amount of money saved per month $\left(\tau_{b}=-0.187^{* *}, P<0.05\right)$. Moreover, the length of the full cycle has a negative correlation with the amount of loan borrowed $\left(\tau_{b}=-0.079, P>0.05\right)$.

The average length of a contribution cycle, i.e. regular period after which members make savings, is 1 month. The length of the contribution cycle has a negative relationship with the minimum contribution per cycle $\left(\tau_{b}=-0.090, P>0.05\right)$. It also has a negative relationship with the amount of money saved per month $\left(\tau_{b}=-0.006, P>0.05\right)$. Moreover, the average minimum amount of savings per contribution cycle is KShs 573.12. The minimum amount of savings per contribution cycle has a positive correlation with the amount of money saved per month $\left(\tau_{b}=0.241^{* *}, P<0.05\right)$.

The average amount of savings contributed per member per month was KShs 1,670. The amount of savings has a positive correlation with the maximum amount of money borrowable from the informal microfinance institution $\left(\tau_{b}=0.049, P>0.05\right)$. The amount of savings also has a positive correlation with the amount of loan accessed $\left(\tau_{b}=0.350^{* *}\right.$, $P<0.05)$. Members in informal microfinance that that don't borrow from external funders contribute more savings as confirmed by Kendall's tau b correlation analysis $\left(\tau_{b}=0.181^{* *}\right.$, $P<0.05)$. Furthermore, informal microfinance institutions that have higher savings have better loan repayment performance. This is because the amount of saving has a negative correlation with the number of delayments in loan repayment $\left(\tau_{b}=-0.039, P>0.05\right)$.

The savings contribution characteristics of the informal microfinance institutions are further illustrated in Table 4.

Table 4: Savings contribution characteristics

\begin{tabular}{|c|l|l|c|}
\hline \multicolumn{4}{|l|}{ Contribution of saving's in informal microfinance institutions } \\
\hline$\#$ & Variable & Statistic & Value \\
\hline 1 & Full cycle (Months) & Average & 14.34 \\
\cline { 3 - 4 } & & Minimum & 12 \\
\cline { 3 - 4 } & & Maximum & 36 \\
\cline { 3 - 4 } & & Standard deviation & 6.196 \\
\hline 2 & Contribution cycle (Months) & Average & 1 \\
\cline { 3 - 4 } & & Minimum & 0.25 \\
\cline { 3 - 4 } & & Maximum & 5 \\
\cline { 3 - 4 } & & Standard deviation & 0.235 \\
\hline
\end{tabular}




\begin{tabular}{|c|l|l|c|}
\hline \multicolumn{4}{|l|}{ Contribution of saving's in informal microfinance institutions } \\
\hline$\#$ & Variable & Statistic & Value \\
\hline 3 & Minimum contribution per cycle (KShs) & Average & 573.12 \\
\cline { 3 - 4 } & & Minimum & 50 \\
\cline { 3 - 4 } & & Maximum & 2000 \\
\cline { 3 - 4 } & & Standard deviation & 599.051 \\
\hline \multirow{2}{*}{4} & Savings per month (KShs) & Average & 1670 \\
\cline { 3 - 4 } & & Minimum & 20 \\
\cline { 3 - 4 } & & Maximum & 25000 \\
\cline { 3 - 4 } & & Standard deviation & 2784.884 \\
\hline
\end{tabular}

\subsubsection{Loan lending}

The average number of times members borrowed loans from informal microfinance institutions in year 2018 is 5 times. The number of times a members borrows loans has a negative correlation with the maximum amount borrowable per time as affirmed by Kendall tau b statistical test $\left(\tau_{b}=-0.069, P>0.05\right)$. It is however positively correlated to the total amount of loan borrowed $\left(\tau_{b}=0.353^{* *}, P<0.05\right)$. Members in informal microfinance institutions that don't borrow money from external sources borrow loans more frequently from the group $\left(\tau_{b}=0.024, P>0.05\right)$. Informal microfinance institutions whose members borrow loans more frequently have higher loan repayment performance. This is confirmed by the negative correlation observed between the number of times members borrowed loans from the group and the number of delayments in loan repayment i.e. $\left(\tau_{b}=-0.095^{*}, P<0.05\right)$.

The average maximum amount of money that a member can borrow from the informal microfinance institutions per time is KShs 19,125. The maximum amount of loan borrowable has a positive correlation with the total amount of loans borrowed $\left(\tau_{b}=\right.$ $\left.0.208^{* *}, P<0.05\right)$. Informal microfinance institutions that don't borrow money from external sources have a lower maximum amount of loan borrowable from the group per time $\left(\tau_{b}=-0.116^{* *}, P<0.05\right)$. Informal microfinance that allow members to borrow more money per time have lower loan repayment performance. This is as affirmed by the positive correlation between the maximum amount of loan borrowable per time and number of delayments in loan repayment $\left(\tau_{b}=0.062, P>0.05\right)$. Moreover, informal microfinance institutions that allow members to borrow higher amounts of loan per time are marked by higher levels of diversion of borrowed money to other uses other than the intended purpose i.e. $\left(\tau_{b}=-0.068, P>0.05\right)$.

The average amount of loans borrowed from informal microfinance institutions per respondent in year 2018 was KShs 27,101. Informal microfinance institutions that don't borrow money from external sources are marked by higher total amounts of loan borrowed by members from the group $\left(\tau_{b}=0.136^{* *}, P<0.05\right)$. Informal microfinance institutions whose members borrow higher amounts of loans in total have higher loan repayment performance. This is as affirmed by the negative correlation between total amount of loan borrowed and number of delayments in loan repayment $\left(\tau_{b}=-0.058\right.$, $P>0.05$ ). Moreover, the higher total amount of loan borrowed by members the higher the levels of diversion of borrowed money to other uses other than the intended purpose i.e. $\left(\tau_{b}=-0.232^{* *}, P<0.05\right)$. 
Further, $27.8 \%$ of the informal microfinance institutions seek funding from external sources. This involves seeking funding from government lending programs and program run by non-government organizations. Additionally, $16.7 \%$ of the informal microfinance institutions operate under umbrella organizations that support them.

The loan lending characteristics of the informal microfinance institutions are further illustrated in Table 5.

Table 5: Loan lending characteristics

\begin{tabular}{|c|c|c|c|}
\hline \multicolumn{4}{|c|}{ Lending of loans in informal microfinance institutions } \\
\hline \# & Variable & Statistic & Value \\
\hline \multirow[t]{4}{*}{1} & \multirow[t]{4}{*}{ Number of times loans accessed in 2018} & Average & 5 \\
\hline & & Minimum & 1 \\
\hline & & Maximum & 28 \\
\hline & & Standard deviation & 5.973 \\
\hline \multirow[t]{4}{*}{2} & \multirow[t]{4}{*}{ Maximum loan borrowable per time (KShs) } & Average & 19125 \\
\hline & & Minimum & 1000 \\
\hline & & Maximum & 90000 \\
\hline & & Standard deviation & 24045.153 \\
\hline \multirow[t]{4}{*}{3} & \multirow[t]{4}{*}{ Amount of loans accessed in 2018 (KShs) } & Average & 27101 \\
\hline & & Minimum & 300 \\
\hline & & Maximum & 360000 \\
\hline & & Standard deviation & 39232.213 \\
\hline
\end{tabular}

\subsubsection{Loan repayment}

The average interest rate charged on loans by the informal microfinance institutions is $10 \%$. The interest rate has a positive correlation with the total amount of loan borrowed by members as confirmed using Kendall's tau b correlation analysis $\left(\tau_{b}=\right.$ $0.029, P>0.05)$. Higher interest rates in informal microfinance institutions translate into better loan repayment performance. This is confirmed by the negative correlation between the interest rate charged and number of delayments $\left(\tau_{b}=-0.015, P>0.05\right)$.

A grace period prior to beginning of loan repayment is allowed by $58.3 \%$ of the informal microfinance institutions with the average grace period being 19 days. The length of the grace period has a positive correlation with the total amount of loan of loan borrowed $\left(\tau_{b}\right.$ $=0.041, P>0.05)$. A longer grace period decreases the loan repayment performance. This is confirmed by the positive correlation between the length of the grace period and number of delayments in loan repayment $\left(\tau_{b}=0.113^{* *}, P<0.05\right)$.

The average maximum loan repayment period allowed to members by the informal microfinance institutions in the study area is 7 months. The loan repayment period allowed by the informal microfinance institution has a negative correlation with the total amount of loans borrowed by members $\left(\tau_{b}=-0.072, P>0.05\right)$. Moreover, allowing a longer loan repayment period leads to lower loan repayment performance. This is as confirmed by the positive correlation observed between the maximum loan repayment period allowed and the number of delayments $\left(\tau_{b}=0.011, P>0.05\right)$.

Follow up of borrowers is done by $44.4 \%$ of the informal microfinance institutions. Follow up is mainly done through visiting the borrowers and asking for purchase receipts. Informal microfinance institutions that follow up borrowers borrow a higher loan 
repayment performance. This is confirmed by the positive correlation between follow up of borrowers and the number of delayments in loan repayment $\left(\tau_{b}=-0.067, P>0.05\right)$.

The study found that $34.5 \%$ of the members had diverted borrowed money to other purposes other than the purpose which they had borrowed the loan in year 2018. Moreover, $1.3 \%$ of the members had defaulted in repaying borrowed loans. Additionally, $31.2 \%$ of the members had delayed in repaying loans borrowed from informal microfinance institutions.

The loan repayment characteristics of the informal microfinance institutions are further illustrated in Table 6.

Table 6: Loan repayment characteristics

\begin{tabular}{|c|c|c|c|c|}
\hline \multicolumn{5}{|c|}{ Repayment of loans in informal microfinance institutions } \\
\hline \# & Variable & Statistic & \multicolumn{2}{|c|}{ Value } \\
\hline \multirow[t]{4}{*}{1} & \multirow[t]{4}{*}{ Interest rate $(\%)$} & Average & \multicolumn{2}{|c|}{$10 \%$} \\
\hline & & Minimum & \multicolumn{2}{|c|}{$1 \%$} \\
\hline & & Maximum & \multicolumn{2}{|c|}{$20 \%$} \\
\hline & & Standard deviation & \multicolumn{2}{|c|}{3.417} \\
\hline \multirow[t]{4}{*}{3} & \multirow[t]{4}{*}{ Grace period (days) } & Average & \multicolumn{2}{|c|}{19} \\
\hline & & Minimum & \multicolumn{2}{|r|}{7} \\
\hline & & Maximum & \multicolumn{2}{|c|}{60} \\
\hline & & Standard deviation & \multicolumn{2}{|c|}{16.205} \\
\hline \multirow[t]{4}{*}{4} & \multirow[t]{4}{*}{ Maximum loan repayment period (months) } & Average & \multicolumn{2}{|c|}{7} \\
\hline & & Minimum & \multicolumn{2}{|c|}{0.5} \\
\hline & & Maximum & \multicolumn{2}{|c|}{12} \\
\hline & & Standard deviation & \multicolumn{2}{|c|}{5.253} \\
\hline \multirow[t]{6}{*}{10} & \multirow[t]{6}{*}{ Number of delayments in loan repayment in 2018} & $1=0$ & 265 & $68.8 \%$ \\
\hline & & $2=1$ & 79 & $20.5 \%$ \\
\hline & & $3=2$ & 28 & $7.3 \%$ \\
\hline & & $4=3$ & 10 & $2.6 \%$ \\
\hline & & $5=4$ & 2 & $0.5 \%$ \\
\hline & & $6=5$ & 1 & $0.3 \%$ \\
\hline
\end{tabular}

4.3.4 Calculation of member's performance in informal microfinance institutions using the informal microfinance performance index

Calculation of the informal microfinance performance index first involved adjusting the variable with negative oriented values i.e. number of delayments in loan repayment for directionality (Table 7).

Table 7: Adjusted value for number of delayments in loan repayment

\begin{tabular}{|c|c|}
\hline Adjusted values for number of delayments in loan repayment \\
\hline Number of delayments in loan repayment & Adjusted value \\
\hline 5 & 0 \\
\hline 4 & 1 \\
\hline 3 & 2 \\
\hline 2 & 3 \\
\hline 1 & 4 \\
\hline 0 & 5 \\
\hline
\end{tabular}


Each of the variables was then normalized and standard index values with relative positions in the range of zero to one arrived at (Table 8).

Table 8: Normalized index values for the variables

\begin{tabular}{|l|l|c|}
\hline Variable & Statistic & $\begin{array}{c}\text { Normalized } \\
\text { index value }\end{array}$ \\
\hline \multirow{4}{*}{ Savings normalized index } & Average & 0.657 \\
\cline { 2 - 3 } & Mode & 0.039 \\
\cline { 2 - 3 } & Standard deviation & 0.110 \\
\hline \multirow{2}{*}{ Loan access normalized index } & Average & 0.075 \\
\cline { 2 - 3 } & Mode & 0.000 \\
\cline { 2 - 3 } & Standard deviation & 0.109 \\
\hline \multirow{2}{*}{ Loan repayment performance normalized index } & Median & 0.908 \\
\cline { 2 - 3 } & Mode & 1.000 \\
\cline { 2 - 3 } & Standard deviation & 0.163 \\
\hline
\end{tabular}

The indicators were then weighted using pairwise ranking matrix (Table 9).

Table 9: Weighting of factors using pairwise ranking matrix

\begin{tabular}{|l|l|c|c|}
\hline \multicolumn{4}{|l|}{ Weighting of indicators using pairwise ranking matrix } \\
\hline$\#$ & Indicator & Rank & Weight \\
\hline 1 & Loan repayment performance & 1 & 3 \\
\hline 2 & Savings & 2 & 2 \\
\hline 3 & Loan access & 3 & 1 \\
\hline
\end{tabular}

The informal microfinance performance composite index was then calculated. The index was then tested for accuracy and robustness using uncertainty analysis and an uncertainty of $2.7 \%$ arrived at giving an indication of very high certainty (Table 10 ).

Table 10: Calculation of accuracy using uncertainty analysis

\begin{tabular}{|l|c|c|c|c|}
\hline Calculation of accuracy using uncertainty analysis \\
\hline Variable & $\boldsymbol{w}_{\boldsymbol{i}}$ & $\boldsymbol{S}_{\boldsymbol{i}}$ & $\boldsymbol{w}_{\boldsymbol{i}} \boldsymbol{S}_{\boldsymbol{i}}$ & $\left(\boldsymbol{w}_{\boldsymbol{i}} \boldsymbol{S}_{\boldsymbol{i}}\right)^{\mathbf{2}}$ \\
\hline Loan repayment performance & 3 & 0.0083 & 0.0249 & 0.00062001 \\
\hline Savings & 2 & 0.0056174 & 0.0112348 & 0.00012622073104 \\
\hline Loan access & 1 & 0.0055541 & 0.0055541 & 0.00003084802681 \\
\hline$\sum\left(w_{i} S_{i}\right)^{2}$ & 0.0007770787 \\
\hline$\sqrt{\sum}\left(w_{i} S_{i}\right)^{2}$ & $0.02787613136 \approx 2.7 \%$ \\
\hline
\end{tabular}

Further, the index was analyzed for sensitivity using multiple regression analysis and a coefficient of determination $\left(\mathrm{R}^{2}\right)$ of 1.00 arrived at giving an indication of very high sensitivity. (Table 11).

Table 11: Calculation of sensitivity using multiple regression analysis

\begin{tabular}{|c|c|c|c|c|}
\hline \multicolumn{4}{|c|}{ Calculation of sensitivity using multiple regression analysis } \\
\hline Model Summary \\
\hline Model & R & R Square & Adjusted R Square & Std. Error of the Estimate \\
\hline 1 & 1.000 & 1.000 & 1.000 & 0.002103415 \\
\hline
\end{tabular}


The average informal microfinance performance index that was arrived at is 0.976 . The median is 1.021 and the mode is 1.021 . The informal microfinance performance index ranges between 1.713 to 0.099 while the standard deviation is 0.189 and the skewness is 0.951. The informal microfinance institutions are therefore mainly marked by high levels of informal microfinance performance.

\subsection{Relationship between structure and performance in informal microfinance institutions}

\subsubsection{Membership characteristics}

Kendall's tau-b correlation analysis was used to determine the relationship between membership characteristics and informal microfinance performance. The observed relationships were as illustrated in Table 13.

Table 13: Relationship between membership characteristics and informal microfinance performance

\begin{tabular}{|c|l|c|c|}
\hline$\#$ & Variable & Coefficient $\left(\tau_{b}\right)$ & Sig $(\boldsymbol{p})$ \\
\hline & Gender & +0.045 & 0.284 \\
\hline & Age & -0.070 & 0.079 \\
\hline & Marital status & -0.074 & 0.068 \\
\hline & Level of education & $+0.144^{* *}$ & 0.000 \\
\hline & If head of household & $+0.142^{* *}$ & 0.001 \\
\hline & How household is headed & $-0.091 *$ & 0.030 \\
\hline & Household size & +0.031 & 0.391 \\
\hline & Member's number of groups & +0.030 & 0.442 \\
\hline & Member's years of membership & -0.021 & 0.554 \\
\hline & Age of group & -0.005 & 0.882 \\
\hline & Number of group members & -0.065 & 0.071 \\
\hline & Group composition by gender & -0.008 & 0.854 \\
\hline
\end{tabular}

\subsubsection{Leadership characteristics}

Kendall's tau-b correlation analysis was used to determine the relationship between leadership characteristics and informal microfinance performance. The observed relationships were as illustrated in Table 14.

Table 14: Relationship between leadership characteristics and informal microfinance performance

\begin{tabular}{|c|l|c|c|}
\hline$\#$ & Variable & Coefficient $\left(\tau_{b}\right)$ & Sig $(p)$ \\
\hline & If member holds leadership position & -0.027 & 0.519 \\
\hline & Number of officials & +0.021 & 0.573 \\
\hline & Term of office & -0.019 & 0.630 \\
\hline & Gender of chairperson & +0.039 & 0.347 \\
\hline & Chairperson level of education & -0.007 & 0.849 \\
\hline & Number of years chairperson has held groups leadership & -0.040 & 0.253 \\
\hline & Number of leadership positions held by chairperson & +0.050 & 0.193 \\
\hline & Allowances to officials & -0.016 & 0.710 \\
\hline
\end{tabular}




\subsubsection{Saving and lending characteristics}

Kendall's tau-b correlation analysis was used to determine the relationship between savings and lending characteristics and informal microfinance performance. The observed relationships were as illustrated in Table 15.

Table 15: Relationship between savings and lending characteristics and informal microfinance performance

\begin{tabular}{|c|l|c|c|}
\hline$\#$ & Variable & Coefficient $\left(\tau_{b}\right)$ & Sig $(p)$ \\
\hline & Contribution cycle & $+0.126^{* *}$ & 0.002 \\
\hline & Maximum loan borrowable & +0.044 & 0.129 \\
\hline & Group access to external funding & $+0.110^{* *}$ & 0.008 \\
\hline & Interest rate & +0.019 & 0.639 \\
\hline & Grace period & -0.051 & 0.204 \\
\hline & Loan repayment Period & -0.038 & 0.340 \\
\hline & Follow up of borrowers & $-0.110^{* *}$ & 0.008 \\
\hline
\end{tabular}

\section{Discussion}

The study aimed to analyze informal microfinance institutions structures in relation to performance. It found that women are the main participants and also perform better in informal microfinance institutions. Moreover, the study found that most informal microfinance institutions are led by female chairpersons with female led groups performing better than men led groups. Women having less income earning opportunities and income levels than men may participate more in informal microfinance institutions to access the more easily accessible and affordable financial services they offer. Women are also more vulnerable and therefore will save more to cushion themselves against future shocks and stresses. Women also have better loan repayment performance which could be due to greater prudence in financial management and in undertaking investment. They are more observant of group rules and more sensitive to peer pressure. The fact that they have less economic opportunities means they will observe set rules and repay loans better to safeguard opportunities for accessing informal microfinance services in future. Greater participation in informal microfinance institutions indicates that women have higher more social capital hence better mutual support systems, better access to social collateral and hence higher informal microfinance performance.

Anderson and Baland (2002) deduce that participation in informal microfinance institutions is higher among women than men in Kenya. Ritchie (2007) in a study in India, Sri Lanka and Indonesia deduces that low income earners in rural areas rely more on informal financial organizations due to poor access to formal financial services. Johnson (2005) in a study in Central Kenya notes that women use informal microfinance institutions more due to smaller income streams which are however more consistent as compared to those of men who receive bigger but less regular lump sum earnings. Female headed households save more money than male headed households (Gedela 2012). Furthermore, Chaudhary and Ishfaq (2003) and Roslan and Abdi Karim (2009) found that male borrowers formed the largest group of loan defaulters. Todd (1996) in a 
study of the Grameen Bank in Bangladesh observes that women have more prudent investment strategies which leads to better performance in informal microfinance institutions. Galema et al (2009) who note that female leaders are more effective since they spend more time on monitoring activities.

The study found that all informal microfinance institutions have bylaws to govern their activities. These bylaws are developed participatorily by members which reinforces ownership, adherence and thus effectiveness in enforcement. Moreover, activities of informal microfinance institutions are guided by participatorily formulated strategies. Hunjra et al (2014) in a study in Islamabad, Pakistan conclude that strategic planning has a significant positive relationship with performance of microfinance institutions. The informal microfinance institutions were found to differ in terms of leadership characteristics which in turn influence performance.

Savings and lending activities in informal microfinance institutions provide members with financial capital to access capital assets and hence undertake livelihood strategies that lead to desirable livelihood outcomes. Savings and lending activities are based on set terms and conditions which influence informal microfinance performance. These terms and conditions define the saving and lending methodology and hence the nature of contracts in informal microfinance institutions. They also determine the favorableness of the financial services offered by informal microfinance institutions.

The study observes that the informal microfinance institutions are marked by high levels of performance. They have a high level of sustainability as indicated by high dependence on member's savings as lending capital, low reliance on funding from external sources and have low default rates which implies that they will be able to finance future lending activities. They have high loan repayment performance as indicated by the low level of default and delinquency. Moreover the informal microfinance institutions have high social performance given the relatively high membership which indicates high outreach and greater participation of women and vulnerable groups in the community. Performance in informal microfinance institutions is influenced by their structure and saving and lending characteristics.

According Wambugu and Ngugi (2012) microfinance institutions need to be selfsustaining to achieve their outreach potential and provide adequate financial services to poor people. Besides, Al Azzam and Mimouna (2012) deduced that access to loans from commercial banks has a negative influence on the performance of microfinance institutions by reducing their repayment performance and increasing risks. Khandker et al (1995) and (Kereta 2007) note that low default rate indicates higher financial sustainability since the microfinance institution will be able to finance future lending activity. Moreover, Hulme and Mosley (2007) observe that more members means reduced costs and financial sustainability due to economies of scale. Additionally, Zeller and Meyer (2002) observe that outreach to the poor is a key determinant of performance in microfinance institutions.

The fact that most participants in informal microfinance institutions are women and other vulnerable groups means they are an important policy strategy that that should be considered in formulating of policies aimed at improving their livelihoods. These include policies geared towards gender equity, financial inclusion, poverty alleviation, rural development, social welfare and building resilience to climate change and variability. 
Microfinance helps address poverty and foster inclusive growth by providing microcredit which enables low income people to initiate income generating activities, purchase capital assets and cope with economic shocks (Liang et al. 2014).

\section{Conclusion}

The structure of informal microfinance institutions is defined by their membership and governance characteristics. Informal microfinance institutions are governed participatorily based on inclusive bylaws and strategic frameworks. Savings and loan activities in informal microfinance institutions are based on social capital which facilitates savings mobilization and provides social collateral in lending activities. Their savings and lending methodology is defined by mutually agreed terms and conditions. These terms and their structure are the key determinants of informal microfinance performance. Informal microfinance institutions are a key policy strategy for poverty alleviation, gender equity and enhancing resilience of vulnerable people to climate risks. Detailed and context specific analysis of informal microfinance institutions structures is thus imperative to inform policies and programmes for enhancing their performance in provision of financial services and improvement of livelihoods in rural areas.

\section{References}

Al Azzam, M., Momouri, K., \& Ali, M. (2012). The impacts of socioeconomic factors and financial access on microfinance institutions. International journal of economics and finance, 4(4).

Anderson, S., \& Baland, J. (2002). The economics of ROSCAs and intra household resource allocation. Quarterly journal of economics, 117(3): 963-995.

Bourdieu, F. (1986). The forms of social capital. In: J. Richardson (Ed.), Handbook of theory and research for sociology of education (pp. 241-258). New York: Greenwood Press.

Chaudhary, A., \& Ishfaq, M. (2003). Credit worthiness of rural borrowers of Pakistan. The journal of socioeconomics, 32(6): 675-684.

Chiteji, N. (2002). Promise kept; Enforcement and the role of rotating savings and credit associations in an economy. Journal of international development, 14: 393-411.

Cochran, W. (1963). Sampling Techniques, 2nd Edition. New York: John Wiley and Sons Inc.

Coleman, J. (1988). A Social capital in the creation of human capital. The American Journal of Sociology, 94: 95-120.

Galema, R., Lensink, R., \& Mersland, R. (2009). Do powerful CEOs bave an impact on microfinance performance? Centre for International Banking Insurance and Finance. University of Groningen, Nottingham

Gedela, S. (2012). Determinants of saving behavior in rural and tribal households; An empirical analysis of Visakhapatnam District. International journal of research and social sciences, 2(3).

Gomez, R., \& Santor, E. (2001). Membership has its challenges; The effect of social capital and neighborhood characteristics on the effect of microfinance borrowers. Canadian journal of economics, 24(4): 943-966.

Government of Kenya (2008). First medium plan (2008-2012). Government of Kenya.

Government of Kenya (2019). Kenya population and housing census Vol II; Distribution of population by administrative units. Government of Kenya.

Gugerty, M. (2007). You can't save alone; commitment in rotating savings and credit associations in Kenya. Economic development and cultural change, 55(2): 251-282.

Hamby, D. (1995). A comparison of sensitivity analysis techniques. Journal of health physics, 68(2): 195-204.

Hammil, A., Matheu, R., \& MC Canter, E. (2008). Microfinance and climate change adaptation. IDS Bulletin, 39(4).

Hulme, D., \& Mosley, P. (1996). Credit for the poor in Bangladesh. In: D. Hulme \& P. Mosley (Eds.), Finance against poverty (pp. 94-176). London: Routledge. 
Hunjra, A., Shamim, N., \& Khalid, B. (2014). Impact of strategic planning on the financial performance of small and medium banks in Islamabad. Bulletin of Business and Economics, 3(2): 96-130.

Johnson, S. (2005). Fragmentation and embeddedness; an alternative approach to the analysis of rural financial markets. Oxford development studies, 33(3): 357-375.

Kaburi, S., Ombasa, B., Omato, D., Mobegi, V., \& Memba, F. (2013). An overview of the role of microfinance in eradicating poverty in Kenya; A lesson to be learnt from the emerging economies. International journal of arts and commerce, 2(5).

Kereta, B. (2007, 15-17 November). Outreach and financial performance of microfinance institutions in Ethiopia [Paper presentation], African economic conference, Addis Ababa, Ethiopia.

Khandker, S. (1998). Fighting poverty with microcredit; Experience in Bangladesh. Dhaka University Press Ltd.

Kiplimo, J., Ng'eno, E., Koech, W., \& Julius, B. (2015). Determinants of access to credit financial services by small holder farmers in Kenya. Journal for development and agricultural economics, 7(9).

Kirchner, J. (2001). Data analysis toolkit \#5; Uncertainty analysis and error propagation.

Kirraine, C., Sharkey, C., \& Naess, L. (2012). Shaping strategies, factors and actors in climate change adaptation: Lessons from studies in Africa and Latin America. Trocaire.

Liang, H., Marquis, C., \& Sun, S. (2014). Finance and social responsibility in the informal economy: institutional voids, globalization and microfinance institutions. Working paper 15-029. Harvard Business School.

Machira, H., Njati, I., Thiane, S., \& Huku, G. (2014). Accessibility of women enterprise fund among small and micro women enterprise owners in Tharaka South District, Kenya. IOSR JBM, 16(1).

Moser, R., \& Farias, L. (2014). Microfinance and climate change; the case of Agroamigo. EnANPAD.

Mushuku, A., \& Mayisha, J. (2014). Unlocking the door from poverty through rotating savings and credit associations; a study of group based savings in Ward 14 of Gutu District, Zimbabwe. Bangladesh journal of sociology, $1(2)$.

Mwangi, I., \& Ouma, S. (2012). Social capital and access to credit in Kenya. American Journal of Social and Management Science, 3(1): 8-16.

Njeri, R., Mugambi, F., \& Mutua, N. (2013). Determinants of growth of microfinance organizations in Kenya; A case study of small microenterprise program (SMEP). European journal of accounting, auditing and finance research, 1(3): 43-65.

Oppiah, K., Turkson, J., \& Hagan, P. (2016). The Role of Micro Financial Institutions in Ghana: The Small and Medium Enterprise Perspective Kwame Nkurumah University of science and technology. https://www.researchgate.net/publication/228149417

Osei-Assibey, E. (2011). Microfinance in Ghana: A Comparative Study of Performance of the Formal versus Informal Rural Financial Institutions. Japan: Nagoya University Press.

Ostrom, E., \& Ahn, T. (2009). The meaning of social capital and its link to collective action. USA, Northampton

Owusu, J., Al Hassan, M., \& Nyarko, B. (2011). Assessment of climate shift and crop yields in the Cape Coast area in Central region of Ghana. ARPN journal of agricultural and biological science, 6(2): 49-54.

Putnam, R. (1995). Bowling alone; Americas declining social capital. Journal of democracy, 6(1).

Ritchie, A. (2007). Community based financial organizations; A solution to access in remote rural remote areas? ARD Discussion paper, No. 34. World Bank, Washington DC.

Roslan, A., \& Abdi, K. (2009). Determinants of microcredit repayment in Malaysia; The case of Agro bank. Humanity and social sciences, 4(1): 45-52.

Swain, B., \& Flero, M. (2007). Effect of microfinance on vulnerability, poverty and risk in low income households. Working paper, No. 31. Department of economics, Uppsala University, Sweden

Thrikawala, S., Locke, S., \& Reddy, K. (2013). Social performance of microfinance institutions (MFIs); Does existing practice imply a social objective? American journal of business and management, 2(2): 173-180.

Tilakaratna, S. (1996). Credit schemes for the rural poor; some conclusions and lessons from practice. Issues in development Discussion paper, No. 9. International Labour Organization.

Todd, H. (1996). Women at the centre; Grameen Bank borrowers after one decade. USA: Westview Press.

Wambugu, F., \& Ngugi, J. (2012). Factors influencing sustainability of microfinance institutions in Kenya; A case study of Kenya Women Finance Trust. International journal of innovative research and development, 1(11): 519-537.

Zeller, M., \& Meyer, R. (2002). The triangle of microfinance; Financial sustainability, outreach and impact. International Food Policy Research Institute, Washington DC. 